\title{
TRAINING FOR THE FUTURE
}

\section{J. C. BEENHAKKER, B.Sc. (Physio) (Rand)* D.P.E. (Rand)}

Dit is noodsaaklik dat die opleiding van fisioterapeute Drien word in die lig van die huidige en toekomstige beherstes van die gemeenskap. Projekte wat in 1975 en the four voorgraadse studente aan die Universiteit van 1976 Witwatersrand onderneem is, bring die behoefles en die Wrikominge in die leergang aan die lig. Melodes om lekrlie uildagings te benader word bespreek en die behoefte aan diepgaande navorsing omtrent opleiding word beklemioon.

In order to ensure that our students will be able to meet the challenge of the future, more thought must mee given to curriculum design and planning.

At present one of the functions of the Professional Board and of the South African Society of Physiotherapy is to maintain standards of training in order ensure that on graduation the physiotherapist is tompetent and capable of being "let loose on the public".

Who decides upon these standards? Minimum standards have been laid down regarding the number of hours of clinical training required before a student may graduate. Certain syllabuses have been accepted as meeting the requirements of training and are often based on those from United Kingdom training centres.

Do any of these standards ensure that we are really training physiotherapists who will be equipped to practice in our country with its different problems and needs? Have these standards ever been put to the test to ensure that they are what the profession requires from its members?

The necessity for objectives in Medical Education is not a new concept and a wealth of literature is available from America and Great Britain especially. This obviously also applies to physiotherapy and if we are to keep up with advances in Medical Education we must review our training in earnest.

This has not escaped the Lecturers' Group of the South African Society of Physiotherapy and members from all training centres are committed to the problem of evaluating physiotherapy education by defining its objectives and investigating means of achieving these objectives.

There is a danger that, in maintaining the high stanTards which have been arrived at arbitrarily, a certain Sigidity will develop which will be an obstacle to change. Many of these standards are also artificially high and do not bear much relationship to the social needs of the community in which our physiotherapists will serve.

Can we be certain that our examination system is ensuring that students have assimilated sufficient knowledge to cope with the problems that they will encounter in dealing with the patient, his family and all members of the health team? Great stress is laid on motor skills and basic knowledge, but are these the only criteria for assessing a professional person?

There is a danger that we may be training students to pass examinations, rather than aiming to produce a professional person with an enquiring mind who is adaptable and creative. There is a great deal of evidence that students who do well in examinations do not necessarily make the best physiotherapists. Furneaux ${ }^{3}$ even found that the neurotic introvert was the one who did best in examinations!

* Senior Lecturer, Acting Head. Sub Department of Physiotherapy, University of the Witwatersrand.
Our present examination system tends to influence the teaching of an excessive amount of factual knowledge and, as Professor Simpson" says, "tests become self-confirming, becausc what they measure best is the special training the candidates have been given to precondition them for the experience of being cxamined". Students learn to answer in the way that they think the examiner wishes them to reply and we all know that, in our training schools, the students find out who their examiners will be in order to gear their replies in this direction. This leads them to anticipate what the examiner would like to hear and does not reflect what they have really learnt or how they would apply this knowledge.

In order to maintain these high standards, it is felt that a reasonable failure rate is essential. However, it is common knowledge that the bell-shaped curve should not apply to education. The standard of students entering the training centres is becoming increasingly high and our students are a very select body of persons. One should expect most of them to do well, yet, when an examiner marks consistently high. she is accused of having very low standards.

The whole method of examination necds to be revised in order to ensure that what we are testing is truly reflective of the student's ability to apply, analyse, synthesise and evaluate, and is not merely a test of recall and of simple motor skills.

This can only follow when the objectives have been defined. With this in mind, several workshops have been held this year regarding the curriculum. Until we are sure of what these objectives are and how they can be evaluated, we will not be sure of what the examinations are measuring.

I strongly believe that the training of students in our country is adequate and that we are producing good potential physiotherapists. With basic training, which should include scientific research methods, the student will gain the ability to question, reason and apply her knowledge. She should be able to evaluate a patient as regards his disability and to plan a programme of treatment to suit his needs, within the available resources of the community. She should know where to go for advice about alternative treatment programmes and must obviously be aware of what these alternatives are.

No student can possibly become perfect in every technique that is thought to be necessary, but the student who has a good educational training will be able to modify and adapt after graduation. None of us can boast of proficiency in all the various techniques, so how can we expect our students to acquire these skills in the few years of study? Many techniques expected of students are, to my mind, specialties in which the graduate can do an in-depth study at a later stage.

The physiotherapist of the future will have to have a greater vocation for service to her country rather than for the treatment of the individual. There will have to be a move away from a totally hospital-oriented training to one of community health in a multi-disciplinary team. The physiotherapist will therefore have to be able to work independently in the community and to work in a peer relationship with other professional people.

Other members of the health team are not informed of what role physiotherapy can play and, in a survey done by $R$. Fehler ${ }^{2}$ as an undergraduate in 1975 , it was obvious that the knowledge of the medical 
profession regarding our profession is very inadequate. It is the responsibility of every physiotherapist to improve this situation.

In order to give our students an opportunity of doing research and of working with medical students, our third year students ioined the medical students in Physiology II this year. It is hoped that they will gain insight into research which will stand them in good stead for their fourth year projects and, hopefully, in working for higher degrees. But, more important, they will have lcarned to work with others in obtaining information and in solving problems.

Methods of evaluating what has been learned are essential and the methods of examining a student will have to be modified. How can we ensure the maintenance of high standards, which are obviously assessed in the examination room where the student is under stress and is not functioning in her normal capacity? Continuing assessment would eliminate part of this problem, providing that we really know what we are assessing.

We have not proved that what we are measuring is that which we hope the student has learned. Rather, we have demonstrated that some students have better recall than others. Most students eventually learn one thing, and that is to pass examinations. When students do fail, or barely pass, observers are satisfied that the standards were high.

Are we then really ensuring that these young people are adequately equipped to meet the challenge of the times? Will they be able to take their place in society as truly professional people? Do our training centres and our professional bodies know what these challenges are and are physiotherapists doing anything about finding the answer?

Research is at present under way at the University of the Witwatersrand to assess what modalities are commonly used by the practising physiotherapist of today and what skills should be acquired by the future physiotherapist. We intend to do in-depth research into some of these modalities and by analysing our tech. niques in this manner we will be able to accept or reject these in terms of scientific evidence.

There is much that still needs to be done and our professional Society should be encouraging research into topics that have true meaning for the profession. Many of the subjects chosen for a higher degree are on obscure or barely-related topics, which do not fulfil the needs of our profession.

What we need are workshops and brain-storming sessions to work out what is required to "provide adequate and reliable physiotherapy services". From these we can work out our objectives of training and of continuing education.

\section{References}

1. Dyer, L., The Changing Role of the Remedial Pro fessions, The Leech, 46, 1, 15, 1976.

2. Fehler, R., Unpublished Undergraduate Project, 1976.

3. Furneaux, W. D., The Chosen Few: An Examination of Some Aspects of University Selection in Britain. Oxford University Press, London, 1961.

4. Glauber, K. A., A New Role for Physiotherapy in Medicine, The Leech, 46, 1, 3, 1976.

5. Johnson, G., In reply to question "What direction should Physical Therapy Education take in adequately preparing future physical therapists", Physical Therapy, 52, 4, 448, 1972.

6. Simpson, M. A., Medical Education - A Critical A pproach. Butterworth London, 1972.

7. Weinberg, L., Unpublished Undergraduate Project. 1976. 